\title{
Design of Education Methods in a Virtual Environment
}

\author{
Roman Yavich $^{1}$, Boris Starichenko ${ }^{2}$ \\ ${ }^{1}$ Ariel University, Ariel, Israel \\ ${ }^{2}$ Ural State Pedagogical University, Yekaterinburg, Russia \\ Correspondence: Roman Yavich, Ariel University, Ariel, Israel.
}

Received: July 23, 2017

doi:10.11114/jets.v5i9.2613
Online Published: August 21, 2017

URL: https://doi.org/10.11114/jets.v5i9.2613

\begin{abstract}
The purpose of the presented article is to review existing approaches to modern training methods design and to create a variant of its technology in virtual educational environments in order to develop general cultural and professional students' competence in pedagogical education. The conceptual modeling of a set of methods for students' training in the conditions of an information-and-communication saturated environment was carried out by means of a subject-design method within the framework of prescriptive theory. This allowed us to allocate the stages in designing the methods of student training when using a virtual educational environment. The presented results reflect the general approach to the design of teacher activity including the design of training methods on the basis of accounting for the primary structural components of educational technologies. The given results of examining the features and the opportunities of the virtual educational environment allow us to define the essence of training methods enrichment as well as mechanisms of self-adjustment and self-improvement for a training methods system in educational information environments, and to formulate conclusions about the impossibility of creating modern educational processes without virtual educational environments.
\end{abstract}

Keywords: virtual educational environment, information and communication technologies in education, methods of virtual training

\section{Introduction}

Within the framework of structural components of general cultural and professional pedagogical students' competence development, the issue of technological literacy formation of future teachers is still urgent. Another important question is the ability to provide learners with assistance in using information and communication technologies (ICT) for organization of successful cooperation, solution of some educational problems, and skill development in modern school ICT-rich educational environments (according to UNESCO recommendations of 2011).

Under these conditions, research in pedagogy and methodology has been carried out (for example, Baltusite \& Katane, 2014, Chatti, 2010; Harmelen, 2009; Izmestiev, 2012; Jadzgevičienė \& Urbonienė, 2013; Shaikh \& Khoja, 2012; Tomberg, 2013; Vayndorf-Sisoeva, 2010; etc.) connected with the study of features, opportunities and conditions for the use of information educational environments of educational institutions, personal educational environments and virtual educational environments. The need to use educational information environments is theoretically justified: the practical use of learning management systems, cloud services and other information educational environments for the solution of educational and organizational tasks extends the educational processes of many higher education institutions. As a result, researching questions of creating techniques for the use of educational information environments, training techniques specific to personalized educational environments (Starichenko, 2013, Starichenko, Sardak, \& Slepukhin, 2015, Starichenko, Boris E., Artem N. Egorov, and Roman Yavich,2013), and what constitutes the essence and features of modern (information and communications) training methods (Semenova, 2014) as well as their classification and design real-time conditions is warranted (Semenova, 2014).

Since this area of educational research is new, there is no single approach to developing a system of teaching methods in the information environment, understanding the relations between methods and forms of educational activities, in addition to the isolating the essence of teaching methods in virtual learning environment conditions.

This paper singles out a particular educational environment, the virtual educational environment (VEE) in order to formulate the current dilemma, the tension between the need to build a technique of student training in virtual 
educational environments so as to build general cultural and professional competence and the ambiguity of understanding the structure of this technique, as well as insufficient development of the technology of designing methods of teaching "modern" educational paradigms. In order to resolve these contradictions, this article presents a variant of teacher training methods designed when using virtual educational environments.

\section{Methodology, Objectives and Research Design}

This article aims to review design approaches to modern training methods and describe the author's technology of such a design for the conditions of the virtual educational environment in the formation of general student cultural and professional competence in the course of pedagogical education.

From the perspective of research methodology, we show how it involves allocation and specialization of VEE features for framing system-wide student competence, correlation of results with stages of educational technology design, meaningful concretization of practices that make up techniques, and implementation of the algorithm for the constructive activity of teacher-student methods for pedagogical specializations. In the process of generating such a methodology, it is necessary to identify and exploit opportunities inherent in educational processes of virtual educational environments, clarify their conceptual apparatuses, and isolate characteristics of students' learning methods in virtual learning environments through the analysis of existing ones design.

So, to justify the technology of the students' training methods design we begin with consideration of the essence and opportunities of using virtual educational environments in educational processes.

In the virtual educational environment, according to modern research (in particular, Paik, Lee, \& McMahon, 2004, Starichenko, 2015, Vayndorf-Sisoeva, 2010), we understand networked communication spaces as those in which educational process are organized, methodical input and information are supported and documented, and interaction between all subjects of educational processes takes place with management support.

Despite the lack of unified approaches in the allocation of VEE structures, it is advisable to pay attention to the interrelation of its components as specified in many studies. These components include personal students' educational environments, personal environments for the teachers' training, global and local networks, learning management systems - LMS, and cloud computing services. From a research point of view( Davidovich, N., Yavich, R., \& Domoshnitsky, A., 2012.), the use of these opportunities offered by this allocated set of components encourages independent trainee activity development and increases the coherence of the knowledge-creating process and the formation of professional and general cultural competence.

In one of the classifications of virtual educational environments, the personal teaching environment (PTE) and the personal learning environment (PLE) are distinguished.

We point out that PLE formation is guided by imperatives of modern hardware supposedly enabled by the online creation of virtual space for the exchange and storage of educational information, facilitation of communication, activity planning, and collection and storing of data related to training results. For the organization of such a space it is expedient (see Maloney \& Smith, 2009, Moothoor \& Bhatt, 2009, Nabil, 2010; Starichenko, 2015) to use cloud technologies and Web 2.0 services. Thus, the environment is built and developed by a trainee, including all components required for the development of educational programs - content, tools, communication and others. A powerful argument in favor of such an environment is the possibility of its further post-graduation development and use, providing some practical support for the concept of continuous lifelong learning (Dayana Abd Halim, Bilal Ali, \& Yahaya, 2010; Lobanov, 2009, 2011; Noguchi, Guevara, \& Yorozu, 2015; Singh, 2015; Scantlebury, 2009).

A personal teaching environment (PTE) can be formed when a teacher selects the necessary network services and tools, and then starts a discipline-specific blog on which members can contribute. Certainly, the teacher can upload all needed training materials there as well as posting links to them and required cloud tools. Hence, the idea of establishing a thematic network community is realized in PTE, which possesses a certain motivational appeal to students.

The virtual learning environment consists of two media aspects: organizational and communicative (according to Vayndorf-Sisoeva, 2010, Starichenko, B., Egorov, A., Davidovitch, N., \& Yavich, R., 2010.), a "self-tuning and self-improving complex communicative system, which provides the link between course participants." Self-tuning is performed by rapid user adjustment of communicative actions and self-improvement is performed through effective communication and the acquisition of ever more complex types of relationships. It is recommended to emphasize these aspects of virtual educational systems when designing teaching methods in ICT-rich environments and building a toolkit of relevant teaching methods, enriched and updated in every phase of the "modern" paradigm development.

We will now focus on a conceptual framework and distinguish specific features of training methods for the virtual educational environment. 
The expansion of educational information spaces leads to the emergence not only of new ICT instruments, but also to the updating of all didactic systems of training, including, first of all, training methods for solving new didactic problems or tasks impossible in an earlier non-virtual era. With the advent of new training methods (in particular, see Semenova, 2014) it is useful to address new ways of applying virtual educational environments in educational processes. We will now discriminate between the concepts of "training methods employing VEE" and "methods of use of VEE in training" in specific contexts.

The first is a set of joint actions by teacher and trainees in order to organize educational information exchange and manage its perception, as well as its understanding, memorization, and correct application with the help of VEE information and communications tools.

The second consists of a set of teacher actions (choosing templates and instruments for educational information transfer, modeling of educational processes, etc.) in concert with information and communications tools used for didactic purposes to diagnose psychological and pedagogical situations. We differentiate the concepts of "method of using VEE by a teacher in training" and "method of using VEE by a trainee in learning." So the latter method is a trainee activity based on tools from the virtual educational environment and is undertaken in order to solve cognitive and (or) educational tasks.

In addition to these definitions, the interpretation of the term method of training by using VEE as follows: both teacher and trainee actions related to broadcasting, processing and assimilation of training VEE material and its potential for offering solutions to educational and cognitive tasks. In this way, VEE acts as a training subject with an educational purpose and is not reduced only to the development of a technological component. VEE also includes the formation of research skills as well as opportunities for developing communications tools.

Self-adjustment and self-improvement of student training methods come not only aby means of a range of tutorials which are part of VEE (and included by the student), but also on the account of didactic opportunities of VEE.

We carried out a short analysis of the existing technologies for the design of students' training methods.

To reveal the essence of training methods design in traditional educational model, we address M.E. Bershadsky and V.V. Guzeev's research, where, in particular, the didactic foundation of educational technology development is presented and the traditional methods of training are analyzed according to: 'model, explanatory, illustrative, heuristic, programmed and problem' (Bershadsky \& Guzeev, 2003).

The selection of a certain training method depends on the following questions:

- Is it essential to actualize entry conditions at the beginning of an educational occupation?

- Is it necessary to formulate intermediate tasks during work on lesson materials?

- Does it offer trainees solutions to intermediate tasks or should they be allowed to arrive at their own choices independently?

- Does it show trainees prepared algorithms for solving final tasks or let them make individual decisions?

The answers to these questions also reflect the logic of the design of training methods in "scientific" (the term by Semenova, 2014) paradigms of education.

In the training model with the use of ICT, the choosing of a training method can be supported by new approaches to modern training method classification. For example, possible design stages (i.e. choices) of a training method with the use of ICT within the ideology of computer didactics (Bespalko \& Starichenko's terminology) can appear as follows:

1. Formulation of the didactic purpose (choice of target category);

2. Selection and correlation of content with activity features of cognitive processing (for example, knowledge acquisition: educational and cognitive tasks for application of visual perception and spatial imagination as well as analysis, synthesis and classification, etc.);

3. Analysis of psychological and pedagogical conditions (i.e. duration of course of study in a discipline; level of academic progress and formation of psychophysiological qualities, trainee personal characteristics; level of technical equipment, etc.);

4. Allocation of actualized pedagogical influences (i.e. presentation of material in complete form and from alternative perspectives; examples of practical situations; organization of repeated control; reduction of redundant arguments; discussion of different audience points of view, etc.);

5. Creation of training methods with ICT use (i.e. methods for improvement of communicative abilities; methods of individual-based training and control); selection of methods of ICT use for the presentation of 
training material, monitoring assessment and diagnostics, correction of trainee development, management of educational cognitive activity, and individualization of educational cognitive activity;

6. Diagnostics of training results and the required correction of training methods, including methods of using ICT and trainee supervision of their reactions to its applied use, establishing the degree of success in achieving defined didactic parameters, etc.

Therefore (Semenova, 2014, Yavich, Roman and Alexandra Gerkerova,2013) a variation on the design of training methods in a mixed training model is presented, including methods of classroom learning as well as asynchronous and synchronous distance learning. The trainees took part in the design and combination of forms and methods of developing new knowledge and abilities.

\section{Results and Discussion}

As stated above, the use of virtual educational environments in educational processes is informed by relevant content as well as methodical and technological features for the design and implementation of training methods. Various designs for training method development will be presented along with the tools for the specialization of the results even while adjusting for peculiarities of virtual specific educational environments. The primary design stages in this educational technology will be supported by the following:

- Diagnostic and self-diagnostic tools to gauge trainee progress, psychophysiological features, educational needs, and professional interests, along with the creation and accumulation of diagnostic data for evaluation of dynamic development of student competency;

- Specification and integration of training tasks and goals, in addition to organizing results into educational achievement levels;

- Selection of didactic units according to training objectives, including units for competence in designing personal learning environments corresponding to components of general professional competence;

- Populating the virtual environment with components, carried out according to training tasks and psychological and pedagogical diagnostic data in the course of joint activity with the teacher;

- Choice of the technique for management of environment, system of information exchange, and forms and methods of control;

- Stage of reflection and evaluation, during which the structural components of individual educational trajectory is confirmed by the student, and the achievement results of the educational goals and performance of educational and informative tasks are traced and comprehended.

For convenience the design stages of training methods in the conditions of the virtual educational environment will be presented in schematic form (fig. 1).

In addition, the concepts such as "information and communication teaching methods," "methods of environmental training," and "methods of virtual training" into the ideology informing the technology will be introduced, to be defined as follows:

- Methods of "environmental" training is a set of joint teacher-trainee actions based on organization and exchange of educational information, management of perceptions, as well as their understanding, memorization and correct application with the help of sources of information and communication included by trainees that comprise a concrete part of the specially created educational information environment.

- Methods of virtual training - the individualized methods of training constructed from the evaluation of content and features populating personal student educational environments, as well as their level of formation and range, combined with other environments in the global information and communication space.

In determining the essence of these methods (Starchenko, 2013), we note that they are information and communication teaching tools with some specific differences, and are based on the actions of teachers transferring a sense of educational information to trainees and their management perception, and understanding, as well as using the correct information and communications technologies. Our definition highlights the following mandatory teacher activities: the organization of students accessing information in an environment defined by its psycho-physiological features and the management of student work based on the targeted monitoring of active interactions with different subjects and objects in the educational information environment.

Also note that the first bifurcation point in the logic design of teaching methods for virtual educational environments is 
due to the fact that the teacher is not guided (not knowing) by the peculiarities of the virtual learning environment, and can design a set of (non-system) teaching methods, gathering them from various sources, including information and communication techniques and technologies based on subjective expert views (preferences).

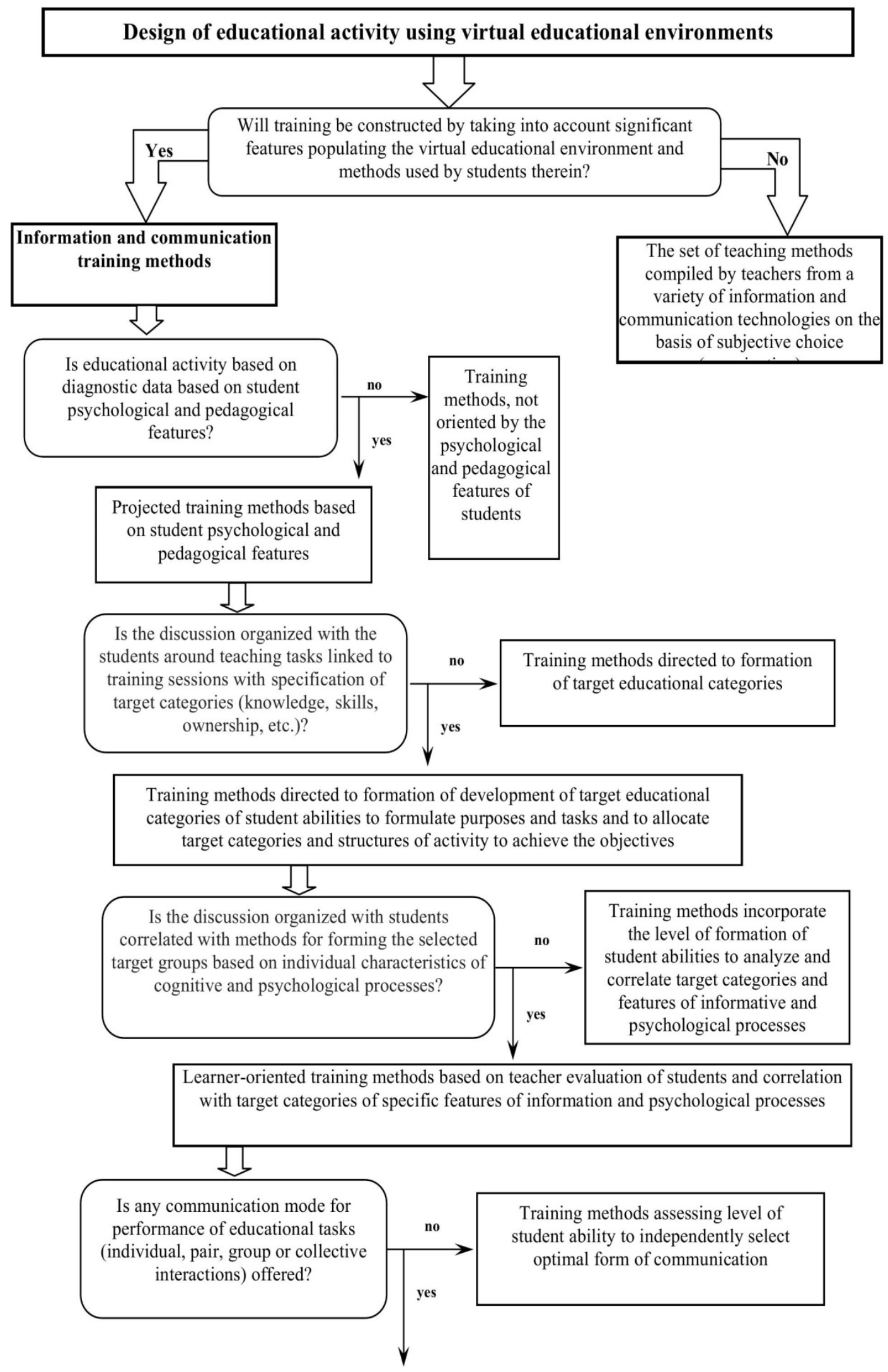




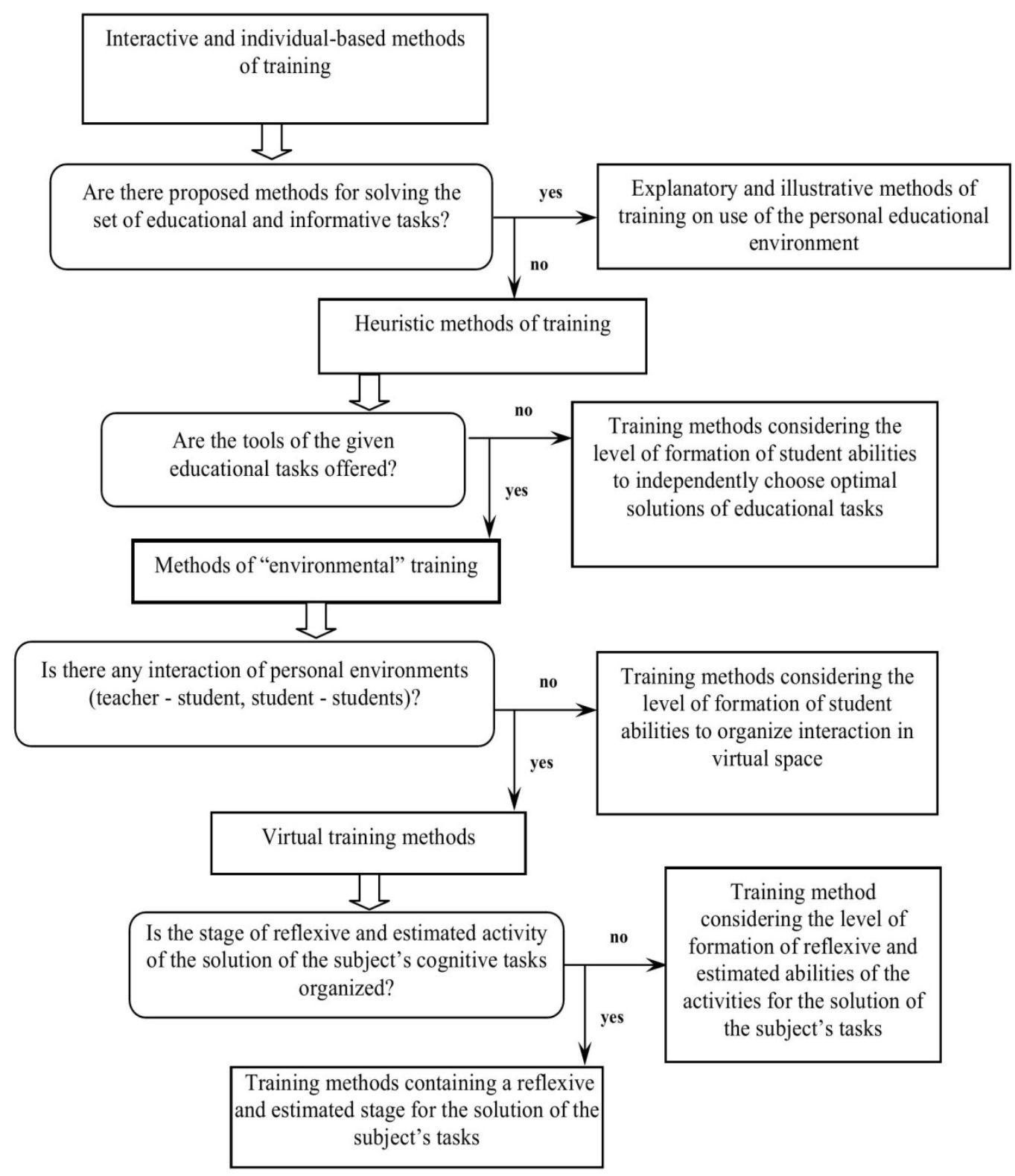

Figure 1. Design of student training methods with the use of personal and virtual educational environments for building general cultural and professional competence

Figure 1 contains fixed features of teacher activities for the design of modern learning processes in the formation of common cultural and professional competencies that must be considered in terms of students populating and using virtual personal learning environments.

The predictive modelling by means of a teaching method algorithm in the field of professional student competence for pedagogical specialties should be considered. Here we point out the need not only to demonstrate ownership of teaching methods and the teacher's technology of choice, but also the advisability of encouraging students to design their own teaching methods. Our studies have shown that an adequate level of formation of the teacher's professional competence must include the ability to build modern teaching methods, and can be achieved with the enrichment of teaching methods by conventional-role reflection (Semenova \& Kuzmina, 2012; Semenova, 2014). Conventional-role reflection is defined as the action of self-knowledge and understanding aimed at developing student awareness of the system itself in the context of the profession in a variety of situations and role-playing duties. The function of conventional-role reflection in situation assessment analysis is not only based on students in simulated teaching situations (see, for example, Wagner \& Herber-Eisenmann, 2009), but also in the process of reflection on methods and techniques in role-playing situations (forms of communication): I-teacher - I-student, I-teacher - We-students, I-teacher - I-teacher, I-teacher - I-pupil and others. 
In view of this, as shown in fig. 1, the algorithm activity contains a special question: "whether organized step-reflexive solutions valuation activity is subject to cognitive and learning tasks?" These result are the response to the selection of conventional-role reflection methods. Implementation of conventional-role reflection in terms of role interaction between students can overcome the traditional crux for trainees performing only part of the joint action and allows us to pass from executive to professional education training: professionals able to make their own decisions. This leads to the importance of educational facilitation (a concept launched by Rogers in the latter half of the $20^{\text {th }}$ century) as a factor in the functioning of conventional-role reflection.

The possibility of using methods that facilitate creative assimilation of the necessary information, formation of reasoning abilities, and the search for new problems in already known material should be examined. In this case, facilitation can be performed by creating certain conditions, which include psychological safety and freedom for experts. These conditions, due to selected features of VEE when linked to cloud services, can be guaranteed as feasible owing to the openness and anonymity of communications and automated monitoring of learning and teaching progress. This is only achieved in the development of methodological subsystems with the purpose of realizing active and interactive information and communication methods of training in cloud service-rich virtual learning environments.

\subsection{Examples}

We illustrate our proposed teaching method design technology by focusing on the use of virtual learning environments and providing a core of designed teaching methods, especially based on teacher-student activities, as well as examples (types of) additional training (cognitive) tasks in the implementation of training activities aimed at the formation of general cultural and professional competences.

Table 1. Illustration of the design of student information and communication training methods in terms of using a virtual learning environment

\section{The activities of the teacher \\ The activities of the student \\ Examples of educational and cognitive tasks}

On the basis of student

psychological and

pedagogical features

activities are organized

and educational

material provided as

well as educational

activity controlled,

monitored and

diagnosed such that the

communication mode

is selected by means of

information

communication

technologies

and
Discuss teaching goals and objectives, establish the connection between objectives and methods, forms of teaching, carry out the proposed learning activities, self-test the results of training activities and the development component of competencies, provide the components of personal learning environments, use tools for populating the components of personal learning environments set up by means of educational interactions, and evaluate the degree of communication (direct and feedback), implemented by the selected tool
1. Specify the urgency for development of information (personal, virtual) learning environments in terms of your personal development, subject knowledge, skills, and professional development (growth).

2. Scroll to the structural components of personal information for virtual educational environments for personal training (for your work as a teacher) and the training of your pupils.

3. Give examples of ICT tools, cloud services for development of the structural components of personal (virtual) learning environments of students and teachers.

4. Select from the examples of ICT tools: cloud services are optimal for you in terms of convenience of interface, solution of educational and vocational-oriented tasks, etc. 
Table 2. Illustration of the design of student interactive teaching methods in terms of using a virtual learning environment

\begin{tabular}{|c|c|c|}
\hline $\begin{array}{l}\text { he activities of the } \\
\text { acher }\end{array}$ & The activities of the student & Examples of educational and cognitive tasks \\
\hline $\begin{array}{l}\text { Organizes activities, } \\
\text { educational materials } \\
\text { and controls, monitors } \\
\text { and diagnoses the } \\
\text { activities by means of } \\
\text { information and } \\
\text { communication } \\
\text { technologies by taking } \\
\text { into account } \\
\text { psychological and } \\
\text { pedagogical features of } \\
\text { students }\end{array}$ & 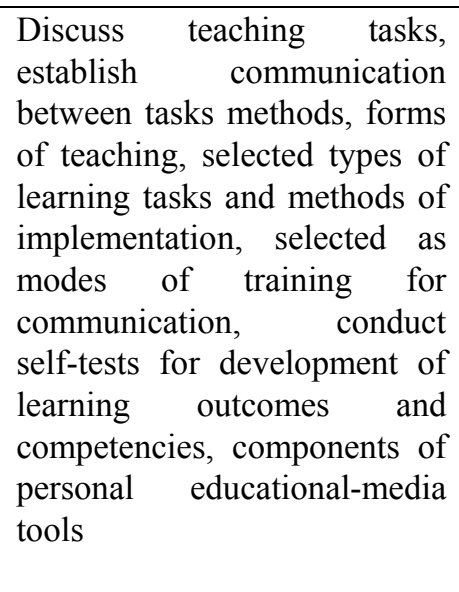 & $\begin{array}{l}\text { 1. Select and map in your chosen cloud service features } \\
\text { of the examples of ICT tools for the development of } \\
\text { each structural component of personal (virtual) } \\
\text { educational environments. } \\
\text { 2. Specify in the cloud service capabilities considered } \\
\text { as ICT tools for development of each structural } \\
\text { component of personal (virtual) educational } \\
\text { environments and arrange them in order of priority } \\
\text { for the organization of educational interaction (for } \\
\text { professional-oriented tasks, etc..). } \\
\text { 3. Evaluate the possibility of implementing interactive } \\
\text { teaching methods in educational information media. } \\
\text { 4. Organize a group discussion of the results. }\end{array}$ \\
\hline
\end{tabular}

Table 3. Illustration of the design of student methods of environmental education in terms of using a virtual learning environment

\begin{tabular}{|c|c|c|}
\hline $\begin{array}{l}\text { The activities of the } \\
\text { teacher }\end{array}$ & The activities of the student & Examples of educational and cognitive tasks \\
\hline $\begin{array}{l}\text { Organizes activities } \\
\text { based on educational } \\
\text { material, educational } \\
\text { activity controls, } \\
\text { monitors and } \\
\text { diagnoses the activity } \\
\text { and organizes the } \\
\text { communication of } \\
\text { personal security } \\
\text { for the instructor } \\
\text { (educational } \\
\text { information } \\
\text { environment) by } \\
\text { taking into account } \\
\text { psychological and } \\
\text { pedagogical features } \\
\text { of students, } \\
\text { implements stage of } \\
\text { reflection on the } \\
\text { results of student } \\
\text { educational activity. }\end{array}$ & $\begin{array}{l}\text { Constructs a component of the } \\
\text { educational environment, } \\
\text { discussing their relationship as } \\
\text { part of the educational } \\
\text { information environment, has } \\
\text { the ability to perform learning } \\
\text { tasks and educational means of } \\
\text { communication in the } \\
\text { information anvironment, } \\
\text { conducts a self-test and a } \\
\text { reflection on the results of } \\
\text { training activities and the } \\
\text { development component of the } \\
\text { competencies, assesses the role } \\
\text { of information educational } \\
\text { environment for professional } \\
\text { use, the design and use of } \\
\text { teaching methods during } \\
\text { teaching practice, chooses the } \\
\text { specific role in the situation and } \\
\text { evaluates the degree of usability } \\
\text { in the environment under certain } \\
\text { (specified teacher or selected } \\
\text { independently) characteristics }\end{array}$ & $\begin{array}{l}\text { 1. Highlight the advantages and disadvantages of using } \\
\text { personal (virtual) learning environments, educational } \\
\text { information environment of your educational } \\
\text { institution in the educational process. } \\
\text { 2. Place in the chosen (or coherent group) cloud service } \\
\text { characteristics of educational environments in order } \\
\text { of priority for media organizations: } \\
\text { a) educational interaction. } \\
\text { b) presentation of educational information. } \\
\text { c) organization of a laboratory of practical work. } \\
\text { d) organization of psychological-pedagogical } \\
\text { diagnostics, } \\
\text { e) organization of educational reflection } \\
\text { f) exchange of experience, teaching materials, etc. } \\
\text { This list of environments independently defined by } \\
\text { the teacher or students so as to carry out searching } \\
\text { for environments (depending on the } \\
\text { psycho-pedagogical characteristics of students). } \\
\text { The forum discussed the possibility of (advantages } \\
\text { and disadvantages) mobile learning organization in a } \\
\text { particular environment and in a particular } \\
\text { role-playing situation. } \\
\text { Organize in the cloud service group discussion of the } \\
\text { results }\end{array}$ \\
\hline
\end{tabular}


Table 4. Illustration of the design of student virtual learning methods in terms of using a virtual learning environment

\begin{tabular}{|c|c|c|}
\hline $\begin{array}{l}\text { The activities } \\
\text { of the teacher }\end{array}$ & The activities of the student & Examples of educational and cognitive tasks \\
\hline $\begin{array}{l}\text { It organizes and } \\
\text { manages } \\
\text { training } \\
\text { activities, the } \\
\text { same, organizes } \\
\text { tutor support of } \\
\text { the educational } \\
\text { process by } \\
\text { means of virtual } \\
\text { learning } \\
\text { environment, } \\
\text { provides stage } \\
\text { of reflection of } \\
\text { the results of } \\
\text { educational } \\
\text { activity of } \\
\text { students }\end{array}$ & $\begin{array}{l}\text { Build individual educational routes in } \\
\text { the virtual space, organize the } \\
\text { interaction of personal learning } \\
\text { environments, including among } \\
\text { teachers, allocate virtual educational } \\
\text { environment components in } \\
\text { accordance with the objectives of the } \\
\text { training (professional activity), } \\
\text { evaluate virtual environments } \\
\text { importance for the realization of } \\
\text { professional activity, conduct an } \\
\text { examination of level of facilitation of } \\
\text { various media (given by the teacher } \\
\text { or found yourself) from the point of } \\
\text { view of the various role-playing } \\
\text { situations, used training techniques } \\
\text { for solving professional problems }\end{array}$ & $\begin{array}{l}\text { 1. Select the options and describe the interaction of } \\
\text { media LMS - PLE - PTE. } \\
\text { 2. Specify the options of filling personal educational } \\
\text { environment in the event of changes in the type of } \\
\text { professional activity. } \\
\text { 3. Propose stages (technology) the choice of a certain } \\
\text { type of environment in a particular psychological } \\
\text { and educational situation. } \\
\text { 4. Organize the Subject in your community group } \\
\text { discussion of the results (or other educational } \\
\text { issues). } \\
\text { 5. Make faceted table for a value judgment formulation } \\
4-5 \text { media (specified teacher or choose your own) } \\
\text { with facilitation positions in specific situations, } \\
\text { role-playing (defined by the teacher or chosen by } \\
\text { yourself). } \\
\text { 6. Analyze the possibility of training your domain in } \\
\text { the massive open online course, the results present } \\
\text { on the site (or by other means designed by you } \\
\text { learning environment). }\end{array}$ \\
\hline
\end{tabular}

\section{Conclusion}

In the modern information society any subject of education needs to adjust to personal educational environments. The possibilities of information and communication spaces allow the student's personal educational environment to be filled automatically with substantial content, with which it is possible to carry out many kinds of educational (and professional) activity throughout life. Therefore, training methods in a modern educational paradigm cannot be projected without its features and subject-matter filling up the student's personal educational environment and virtual learning environment.

Thus, we will note that if the process of the design of modern educational activity is carried out from the position of classical didactics developed in conditions of "scientific" (Semenova, 2014) paradigms, it will inevitably demand, at a certain stage of educational activity, some orientation to the personal educational environment of students and an account of specified features of VEE. However, the fulfillment of the formulated requirements within a "scientific" paradigm cannot be implemented fully and correctly.

So, in a "modern" educational paradigm the student training methods have to focus on the use of personal educational environments within the virtual learning environment. The activities designed have to consider:

- Content and methodical and technological features of the virtual educational environment

- Primary design stages for educational technology,

- Diagnostic data to establish components of general cultural and professional competency for specific student demographics.

This scheme for student pedagogical training is focused on certain components for general cultural and professional competence. Of particular importance are the implementation of reflection and self-reflection methods informing learning activities and teaching methods and the analysis of the possibilities of using these methods in future professional activity for a certain contingent of students. However, it contains the possibility of clarifying and specifying for students learning the other direction on the basis of the theoretical results of the expert, exploring the questions of filling of teaching methods system in the conditions of using virtual learning environment (e.g., Barajas \& Owen, 2000, Lukman \& Krajnc, 2012; Paik, Lee, \& McMahon, 2004; etc.)

These research steps will lead to the development of techniques to harness student abilities to maximize personal educational environments for educational activities. They will also result in techniques for modeling teacher abilities to exploit the possibilities of personal student educational environments to achieve educational goals. 


\section{Acknowledgments}

The work was carried out according to the Ministry of Education and Science of the Russian Federation; grant 2014/392, projects 1942 and 2039.

\section{References}

Baltusite, R., \& Katane, I. (2014). The structural model of the pedagogy students' readiness for professional activities in the educational environment. Rural Environment. Education. Personality, 29-41.

Barajas, M., \& Owen, M. (2000). Implementing virtual learning environments: Looking for holistic approach Educational Technology \& Society, 3(3), 39-53.

Bershadsky, M. E., \& Guzeev, V. (2003). Didactic and psychological foundations of educational technology. Moscow: Teaching Search.

Chatti, M. A. (2010). Personalization in technology enhanced learning: A social software perspective. Dissertation. Aahena University.

Continuous education as a social fact: monogr. (2011): arr. N. A. Lobanov, E. Kula and M. Penkowska; sci. ed. N. A. Lobanov, V. N. Skvortsov; LSU n.a. A. S. Pushkin, Reas. Inst. Soc.-Econ. and Ped. Probl. of the Cont. Educ. SPb.: LSU n.a. A.S. Pushkin. 478 p.

Davidovich, N., Yavich, R., \& Domoshnitsky, A. (2012). Mathematical games: international mathematics olympiad for students. Far East Journal of Mathematical Education, 9(2), 133-140.

Dayana, A. H. N., Bilal, A. M., \& Yahaya, N. (2010). Personalized learning environment: New trend in online learning. http://eprints.utm.my/14943/1/ Personalized_Learning_Environment.pdf

Harmelen, M. (2009). The Manchester personal learning environment. http://www.jisc.ac.uk/events/ $\neg 2009 / 03 /$ ngtip/mple.aspx.

Izmestiev, D. (2012). Personalized learning: A new intenable education approach. UNESCO Institute for Information Technologies in Education. http://iite.unesco.org/pics/publications/en/files/3214716.pdf

Jadzgevičienè, V., \& Urbonienè, J. (2013). The possibilities of virtual learning environment tool usability for programming training. Innovative Infotechnologies for Science, Business and Education, 1(14), 3-9.

Lukman, R., \& Krajnc, M. (2012). Exploring non-traditional learning methods in virtual and real-world environments. Educational Technology \& Society, 15(1), 237-247.

Maloney, N., \& Smith, D. (2009). Oracle managed cloud services enable Bellevue University to cost effectively increase educational opportunities for its students. http://www.oracle.com/us/ corporate/press/2110232

Moothoor, J., \& Bhatt, V. A. (2009). Cloud computing solution in universities. http://www.ibm.com/developerworks/library/ws-vcl/ws-vcl-pdf.pdf. (дата обращения 30.06.2015).

Nabil, S. (2010). Cloud computing for education: A new dawn? International Journal of Information Management, 30 , 109-116. https://doi.org/10.1016/j.ijinfomgt.2009.09.004

Noguchi, F., Guevara, J. R., \& Yorozu, R. (2015). Communities in action lifelong learning for sustainable development. Hamburg, Germany: United Nations Educational, Scientific and Cultural Organization UNESCO Institute for Lifelong Learning.

Paik, W., Lee, J. Y., \& McMahon, E. (2004). Facilitating collaborative learning in virtual (and sometimes mobile) environments. In: Brussler, C. et al (Eds.), WISE 2004 Workshop. LNCS 3307 (pp. 161-166). Berlin Heidelberg: Springer Verlag.

Scantlebury, N. (2009). Collaborative learning using social tools for enquiry, reflection and sharing. In: Ulrich, B. (Ed.), Distance and e-learning in transition, Jearning innovation, technology and social challenges. London: Wiley.

Semenova, I. N. (2014). Methodology of teaching mathematics methods designing in the modern educational paradigm. Yelm, WA: Science Book Publishing House (in Russian).

Semenova, I. N., \& Kuzmina T. A. (2012). Conventional-role reflection as a mechanism of manifestation consistency teaching methods in teacher education students. Teacher education in Russia, 2, 150-153 (in Russian).

Shaikh, Z. A., \& Khoja, S. A. (2012). Role of teacher in personal learning environments. Digital Education Review, 21. http://www.uh.cu/sites/default/files/Role_of_Teacher_in_PLE.pdf

Singh, M. (2015). Global perspectives on recognising non-formal and informal learning. Hamburg, Germany: UNESCO Institute for Lifelong Learning. https://doi.org/10.1007/978-3-319-15278-3 
Starichenko, B. E. (2013). Conceptual basics of computer didactics. Yelm, WA: Science Book Publishing House (in Russian).

Starichenko, B. E. (2015). Professional standards and ICT teacher competency. Teacher Education in Russia, 7, 6-15 (in Russian).

Starichenko, B. E., Artem, N. E., \& Roman, Y. (2013). Features of application of classroom response system at the lectures in Russia and Israel. International Journal of Higher Education 2.3(2013), 23. https://doi.org/10.5430/ijhe.v2n3p23

Starichenko, B. E., Sardak, L. V., \& Slepukhin, A. V. (2015). On interaction of educational environments of different levels. Mediterranean Journal of Social Sciences, 6(5), 486-496. https://doi.org/10.5901/mjss.2015.v6n5s4p486

Starichenko, B., Egorov, A., Davidovitch, N., \& Yavich, R. (2010). Classroom survey systems in teacher lecturing. In Proceedings of the Seventh International Scientific and Practical Conference on Innovative Technologies in Higher Education, 77-82.

Tomberg, V. (2013). Learning flow management and teacher control in online personal learning environment. Tallinn University. Tallinn: Institute of Educational Sciences.

Wagner, D., \& Herbel-Eisenmann, B. (2009). Re-mythologizing mathematics through attention to classroom positioning. Educational Studies in Mathematics, 72(1), 1-15. https://doi.org/10.1007/s10649-008-9178-5

Yavich, R., \& Alexandra, G. Teaching methods and assessment. American Journal of Educational Research 1.7(2013), 260-262. https://doi.org/10.12691/education-1-7-7

\section{Copyrights}

Copyright for this article is retained by the author(s), with first publication rights granted to the journal.

This is an open-access article distributed under the terms and conditions of the Creative Commons Attribution license which permits unrestricted use, distribution, and reproduction in any medium, provided the original work is properly cited. 